\title{
Nasal Cavity and Ethmoid Sinus Cancer pTX TNM Finding v8
}

National Cancer Institute

\section{Source}

National Cancer Institute. Nasal Cavity and Ethmoid Sinus Cancer pTX TNM Finding v8. NCl Thesaurus. Code C133041.

Nasal cavity and ethmoid sinus cancer in which the primary tumor cannot be assessed. (from AJCC 8th Ed.) 